\title{
Ethical Ideology and Ethical Judgments of Accounting Practitioners in Malaysia
}

\author{
Suhaiza Ismail \\ Faculty of Economics and Management Sciences, International Islamic University Malaysia \\ Nazli A. Mohd Ghazali \\ Faculty of Economics and Management Sciences, International Islamic University Malaysia
}

\begin{abstract}
The paper intends to explore the ethical ideology and ethical judgments of accounting practitioners in Malaysia. The objectives of this study are twofold. First, the paper intends to examine the factors that contribute to the different ethical ideology among Malaysian accounting practitioners. Second, it aims to investigate the influence of demographic factors and ethical ideology on ethical judgments of accounting practitioners. The study used Forsyth's (1980) Ethics Position Questionnaire instrument to examine the ethical ideology of the accountants and adopted ethics vignettes used by Emerson et al. (2007) to assess the ethical judgments of the respondents. From the statistical analysis, this study found that age and gender have a significant impact on ethical judgment but not on ethical ideology. In addition, idealism and relativism have a significant influence on ethical judgment, especially in a legally unethical situation.
\end{abstract}

\begin{abstract}
Abstrak: Penelitian ini bertujuan untuk mengeksplorasi ideologi dan pertimbangan etik dari para praktisi akuntansi di Malaysia. Tujuan dari penelitian ini terbagi menjadi dua. Pertama, bertujuan untuk meneliti faktor-faktor yang berkontribusi terhadap perbedaan ideologi etik diantara para praktisi akuntansi di Malaysia. Kedua, bertujuan untuk mengetahui pengaruh faktor demografi dan ideologi etik terhadap pertimbangan etik di antara praktisi akuntansi. Penelitian ini menggunakan instrument kuesioner Etbics Position Questionnaire Instrument (Forsyth's 1980) untuk menguji ideologi etik para akuntan dan mengadopsi sketsa etik yang digunakan (dalam Emerson dkk. 2007) untuk menguji pertimbangan etik dari para responden. Dari analisis statistik, penelitian ini menemukan bahwa usia dan gender memiliki dampak yang signifikan terhadap pertimbangan etik namun tidak pada ideologi etik. Selain itu, idealisme dan relativisme memiliki pengaruh signifikan terhadap pertimbangan etik, terutama pada situasi dimana tidak ada etika hukum.
\end{abstract}

Keywords: accounting practitioners; ethical ideology; ethical judgment; idealism; Malaysia; relativism 


\section{Introduction}

Ethics is crucial in all professions including the accounting profession. The important role of accountants in ensuring the welfare of various stakeholders requires that accounting practitioners maintain a high ethical standard. However, the credibility of the accounting profession has, to some extent, been damaged by the various well-publicised corporate scandals that involved accounting practitioners such as Enron and World.com in the United States of America and Parmalat in Europe. In Malaysia, according to the former president of the Malaysian Institute of Accountants (MIA) there are 'Malaysian Enrons (Abdullah 2007). In particular, the case of an air cargo carrier Transmile Group Bhd whereby the company was alleged for having overstated its revenue by a total of RM522 million for three years from 2005 to 2007. Other financial irregularity cases reported to have occurred in recent years in $\mathrm{Ma}$ laysia that were committed by accountants include Megan Media Holdings Bhd and Wimems Corporation Bhd (Abdullah 2007; and Othman and Abdul Rahman 2010). The seriousness of ethical issues in the accounting profession in Malaysia is a matter of concern of its accountancy profession regulator (i.e. MIA) as voiced by its president (Abdullah 2007).

Despite continuous action by responsible professional accounting bodies such as the issuance of the International Education Standards 4 (IES 4) on Professional Values, Ethics and Attitudes by the International Federation of Accountants (IFAC) in 2003 and the introduction of a compulsory ethics module called Professional Ethics, the Association of Chartered Certified Accountants (ACCA) in 2007 (Abu Bakar et al. 2008) in order to restore the public confidence and credibility of the accounting profession, it is crucial to investigate factors affecting ethical attitudes of accounting practitioners. Furthermore, differences in an individual's characteristics were claimed to affect a person's ethical decision making (see for example: Ferrell and Gresham 1985; Hunt and Vitell 1986; Jones 1991; and Treveno 1986). Similarly, the ethical belief or ideology of an individual has been reported to have an effect on the ethical judgment (see for example: Barnett et al. 1994, 1996; Kim 2003; Kleiser et al. 2003; Steenhout and Keenhove 2006; and Callanan et al. 2010). Hence, the present study intends to investigate the ethical ideology and ethical judgment of accounting practitioners. Even though a burgeoning body of ethics literature has examined the issues of ethical ideology and ethical judgment (for instance: Arrington and Reckers 1985; Hunt and Vitell 1986; Trevino 1986; Shaub et al. 1993; Douglas et al. 2001), most were from developed countries and there is a paucity of published research examining the ethical ideology and ethical judgment in the developing countries, particularly in Malaysia. Moreover, previous studies were reported to have inconclusive findings on the factors affecting ethical ideology and ethical judgment. For example, Forsyth (1980 and 1981), Vitell and Singhapakdi (1993) and Greenfield et al. (2008) claimed to have found ethical ideology to have a significant effect on ethical decision whilst studies by Marques and Azevedo -Pereira (2009) reported an insignificant result. Likewise, mixed results were reported by prior studies on the effect of demographic profile on ethical judgment [for example: Cohen et al. (2001) versus Hartikainen and Tortilla (2004); and Vitell et al. (1991) versus Roozen et al. (2001) on the effect of gender and age respectively on ethical decision]. 
The objectives of this study are twofold. First, this present study intends to examine the demographic factors that contribute to the different ethical ideology among accounting practitioners in Malaysia. Second, this study aims to investigate the influence of demographic factors and ethical ideology on the ethical judgments of Malaysian accounting practitioners. The remaining part of this paper is structured as follows. The next section offers reviews of relevant prior literature on the issues of ethical ideology and ethical judgment.

Then, the following section describes the research methodology of this study including the instrument, the sample respondents, the survey procedures and the statistical analysis adopted in conducting this research. Next, the findings of this study are discussed and finally a concluding section is offered containing implications, limitations of the study and suggestions for future research in the area.

\section{Literature Review and Hypothesis Development}

Generally, this paper addresses two main relationships: (1) the influence of demographic factors on ethical ideology; and (2) the effect of demographic factors and ethical ideology on ethical judgment. Hence, the review of literature covers these key issues and the hypotheses are presented accordingly.

\section{Ethical Ideology}

Ethical ideology, also known as ethical orientation or ethical philosophy, refers to a set of beliefs, attitudes, and values that guide individuals in making decisions on ethical is- sues (Forsyth and Nye 1990; and Barnett et al. 1994). Forsyth (1980) proposed that differences in ethical ideology between individuals could be explained by two factors; idealism and relativism. Idealism refers to the extent to which a person believes that a positive outcome is the result of taking the most ethical action. Idealists believe that harming others is universally not acceptable and should be avoided, even in cases of situational urgency (Forsyth 1980, 1992). Relativism, however, refers to the extent to which a person rejects universal moral rules in making ethical decisions. Relativists weigh specific circumstances and personal values more than the relevant moral rules when distinguishing between right and wrong (Forsyth, 1980; 1992).

\section{Ethical Ideology and Ethical Judgment}

Ethical ideology is claimed to be an important factor that influences an individual's ethical judgment (Schlenker and Forsyth 1977; Forsyth 1980; Hunt and Vitell 1986). Ethical judgment refers to the degree to which a particular behaviour is considered ethical by an individual (Reidenbach and Robin 1990). In making ethical judgment, idealists use idealistic rather than practical criteria (Swaidan et al. 2003). Highly idealistic individuals 'assume that desirable consequences can, with the "right" action, always be obtained' (Forsyth 1980: 176). In contrast, less idealistic individuals do not believe that their action should always produce positive consequences, since they admit that undesirable consequences may sometimes be necessary to achieve a greater good (Forsyth 1980 and 1992). In relation to relativism, a highly relativist individual declines to rely on moral rules in making decisions on ethical matters 
(Forsyth 1980). While less relativistic individuals tend to act in conformity with universal moral principles (Forsyth 1992).

Abundant literature has examined the impact of ethical ideology on the ethical judgments of people from various backgrounds including accounting and other business related professions (Arrington and Reckers 1985; Trevino 1986; Shaub et al. 1993; Douglas et al. 2001). Prior evidence suggests that highly idealistic individuals, who believe that it is possible to avoid harm to others if the morally right action is undertaken, have been reported to judge unethical matters more strictly (Forsyth 1980, 1981, and 1985). Whereas, highly relativist individuals who strongly reject absolute rules and law but closely investigate the situational factors that contribute to one's action, have a tendency to be more lenient in making ethical decisions (Forsyth 1980, 1981, and 1985; Vitell and Singhapakdi 1993). This is in agreement with the findings by Arrington and Reckers (1985) who also claimed that more idealistic (relativistic) individuals judged tax evasion as more (less) serious, and were more (less) likely to view tax compliance as a social norm. Likewise, Greenfield et al. (2008) assessed the ethical orientation of business students concerning earnings management decisions and claimed a significant relationship, in which more idealistic (relativistic) individuals were less (more) likely to engage in earnings management behaviour. Douglas et al. (2001) found that more idealistic auditors rated questionable actions more negatively and Shaub et al. (1993) reported that highly relativistic auditors were less sensitive to ethical situations. Other studies that found a significant positive (negative) relationship between idealism (relativism) and ethical judgment include Barnett et al. (1996), Kim (2003), Kleiser et al. (2003), Steenhout and
Keenhove (2006) and Callanan et al. (2010). In contrast, Barnett et al. (1994) claimed to have found a significant negative relationship between idealism and ethical judgment. A more recent study by Marques and AzevedoPereira (2009) claimed to find no significant relationship between the ethical ideology and ethical judgment of accountants in Portugal. Despite the mixed findings on the relationship between ethical ideology and ethical judgment, evidence from the majority of prior empirical studies implies that highly idealistic (less relativistic) individuals tend to be more intolerant of ethical situations; hence the following hypotheses are offered:

\section{H1:Idealism is positively associated with ethical judgment \\ H2: Relativism is negatively associated with ethical judgment}

Barnett et al. (1994), who investigated the effects of ethical ideology on ethical judgment of business students, suggested that ethical ideology is a stronger influential factor in explaining the ethical judgment of individuals when the situation is more unethical. The finding was supported by Bass et al. (1998) who only found significant differences in ethical judgments due to ethical ideology in the scenario judged most unethical, and also by Douglas et al. (2001) who evaluated the effect of ethical orientation on ethical judgments of 368 accountants from two international accounting firms and found that ethical orientation is related to ethical judgment in high moral intensity situations. This suggests that ethical ideology can influence ethical decisions depending on the level of severity of the matter. In other words, looking from legal perspective, as ethical conducts can be judged as either legal or illegal (Emerson and Conroy 2004; Emerson et al. 2007), the illegal ethical conduct is considered as 
more severe than the legal ethical conduct.

The relationship between ethical ideology and ethical judgment will therefore depend on the legality status of the ethical issue (i.e. severity or seriousness of the ethical conduct). Specifically, a more idealistic (less relativistic) person will be less accepting of an ethical situation that is violating the law than if the ethical situation is not legally wrong as illegal conduct will normally result in greater harm or more negative implications (Emerson and Conroy 2004; Emerson et al. 2007). As the present study considers the influential factors of ethical judgment in two ethically questionable scenarios, which are different in terms of their legality based on the decision of the criminal court, and from the above discussion, the following hypotheses are also tested in this study:

H3: There is an association between ethical ideology and ethical judgment in an illegal ethical situation

H4: There is an association between ethical ideology and ethical judgment in a legal ethical situation

\section{Factors Influencing Ethical Ideology and Ethical Judgment}

Prior research in the area of ethics has demonstrated that age, gender and academic qualifications are the potential determinants of ethical ideology and ethical judgment. Hence, the subsequent review of the literature will cover earlier studies that have attempted to investigate the influence of each of these determinants on ethical ideology and ethical judgment and the relevant hypotheses are proposed.

\section{Gender}

Based on previous studies, gender is an important determinant in explaining the dif- ferences in ethical ideology and ethical judgment. Although there were studies that found no significant difference between gender and ethical ideology (see for instance: Forsyth et al. 1988; Singhapakdi et al.1999; Swaidan et al. 2003; Fernando et al. 2008; and Marques and Pereira 2010), a number of other studies reported a significant relationship between gender and ethical ideology. Barnett et al. (1994 and 1996) and Singhapakdi and Vitell (1994) found that women were more idealistic and more relativistic than men. Hartikainen and Tortilla (2004) claimed that women were more idealistic and less relativistic than men. Similarly, Bass et al. (1998) and McHoskey (1996) reported that women were more idealistic than men, however, neither study found a significant difference in the relationship between gender and the level of relativism. Although the empirical findings on gender differences of ethical ideology were mixed, to some extent, prior studies tend to concur that women are more idealistic than men. However, less evidence was found concerning the relationship between gender and relativism. Hence, the following hypotheses are proposed in this study:

H5: Female accounting practitioners will have a higher level of idealism than male accounting practitioners

H6: There will be a difference in the relativism level for female and male accounting practitioners

Although there has been an abundance of studies that investigated the influence of gender on ethical judgment, the results were inconsistent. A meta analysis by Borkowski and Ugras (1998) reported that nearly half of the studies yielded a significant result on the relationship between gender and ethical judgment. A number of studies reported that women have higher ethical attitudes than men (Akaah 1989; Cohen et al. 2001; Dawson 
1997; Ruegger and King 1992; Weeks et al. 1999). There were also studies that found no significant differences between the ethical judgments of men and women (Hartikainen and Tortilla 2004; Radtke 2000; Serwinek 1992; Shafer et al. 2001; Sikula and Kosta 1994; Stanga and Turpen 1991). Based on the previous results that claimed that females are stricter than men in their ethical decisions, the hypothesis on the relationship between gender and ethical judgment for this study will be as follows:

\section{H7:Female accounting practitioners will make stricter ethical judgments than male practitio- ners}

\section{Age}

Age is another factor that has been claimed to influence the ethical ideology and ethical judgment of an individual. Vitell et al. (1995) reported a positive relationship between age and idealism, which suggested that older people tend to have greater concern for the welfare of others than self-interest. Moreover, older people tend to rely more on universal moral principals when making ethical judgments, which suggests a negative relationship between age and relativism (Bass et al. 1998, Fernando et al. 2008). These arguments were supported by Bass et al. (1998), and Hartikainen and Torstila (2004), whose studies claimed that older people are more idealistic and less relativistic than those who are younger. Hence, the following hypotheses will be tested:

H8: Older accounting practitioners will be more idealistic than younger accounting practitioners

H9: Older accounting practitioners will be less relativistic than younger accounting practitioners

Kohlberg $(1969,1984)$, in his proposed theory of moral cognitive development, claimed that mature individuals have a higher level of ethical judgment than younger individuals. A number of prior studies including Rawwas and Singhapakdi (1998), Vitell et al. (1991) and Ruegger and King (1992) supported this idea in which age is positively related to ethical judgment. However, there are also studies that found a negative relationship between age and ethical decision making, for instance, Roozen et al. (2001) and Sankaran and Bui (2003), who observed that older people were less ethical than those who were younger. Consistent with Kohlberg's theory, this present study predicts a positive relationship between age and ethical judgment; hence, the following hypothesis is proposed:

H10: Older accounting practitioners will have a higher level of ethical judgment than the younger accounting practitioners

\section{Academic Qualification}

Academic qualification is another significant determinant for ethical ideology and ethical judgment. In terms of its relationship with ethical ideology, while Bass et al. (1998) claimed that education did not significantly affect the ethical ideology, the studies by Ho et al. (1997) and Singhapakdi et al. (1999) found that individuals with a higher education level were less idealistic than individuals with a lower academic qualification. However, neither study found a significant relationship between academic qualification and the ethical ideology of relativism. Based on the above findings, it is hypothesized that:

\section{H11: Accounting practitioners with a professional qualification will be less idealistic than those without a professional qualification.}

H12: Accounting practitioners with a professional qualification will be different in their level of 
relativism to those without an accounting professional qualification.

In the context of the relationship between education and ethical judgment, there were studies supporting the idea that more educated individuals were more ethical (Browning and Zabriskie 1983; Jones and Gautschi 1988; Razzaque and Hwee 2002; Swaidan 2003). However, similar relationship studies, such as Deshpande (1997), Dubinsky and Ingram (1984), Kidwell et al. (1987), Merrit (1991) and Shafer et al. (2001), found no evidence that education is related to ethical judgment. Although there are mixed findings, rationally the higher education an individual has, the better the person will be in making ethically related decisions. Moreover, as this present study assesses the education level based on whether a person has a professional accounting qualification or not, it is hypothesized that:

\section{H13: Accounting practitioners with a professional qualification will be stricter in making ethical judgments}

\section{Methodology}

\section{Research Instruments}

The questionnaire comprises three sections: demographic information of respondents, ethical position questions and ethical vignettes. In assessing individual ethical orientation or ideology, Forsyth (1980) introduced an instrument called the Ethics Position Questionnaire (EPQ), which was later adopted by many researchers. This study adapted Forsyth's (1980) ethics position questionnaire (EPQ) to measure the respondents' ethical ideology. The EPQ consists of 20 items, of which ten items measure ideal- ism and the remaining ten items are related to relativism. A five-point Likert scale was used ( 1 being "strongly disagree" and 5 being "strongly agree") to measure agreement with each item. For each respondent, the idealism and relativism scores were computed by averaging the responses to the items of each construct. The data reveal Cronbach's alpha values of 0.77 and 0.82 for idealism scale and relativism scale respectively which imply that the scales have adequate internal reliability.

To measure the ethical judgment of the accountants, two vignettes representing questionable ethical situations were used. The vignettes were adopted from Emerson et al. (2007); however, they were initially developed by Longernecker et al. (1989), Clark (1966) and Harris (1991). The first vignette is about underreporting of company's income to reduce taxation and the second vignette is on accounting tricks to conceal. The detailed descriptions of the two vignettes as appear in the questionnaire are as follows:

Vignette 1:A small business received one-fourth of its gross revenue in the form of cash. The owner reported only one-half of the cash receipts for income tax purposes,' and

Vignette 2:A comptroller selected a legal method of financial reporting which concealed some embarrassing financial facts that would otherwise have become public knowledge.'

The difference in the two vignettes is that in one of the two questionable ethical situations the ethical action involved is legal (Vignette 2) based on the criminal legal standards, while in the other situation (Vignette 1) it is an illegal action. ${ }^{1}$ The rational for having the two different types of ethical situa-

\footnotetext{
${ }^{1}$ Emerson et al. (2007) offers greater discussion on the legality status of the situations.
} 
tions is to see if there is difference in the respondents' acceptability of the ethical issue due to the legality of the action.

For each vignette, respondents were asked to indicate their level of acceptance of the described questionable ethical action on a seven-point Likert scale ranging from always acceptable (1) to never acceptable (7). Thus, a higher score implies a lower acceptability to the ethical scenario or a stricter ethical judgment.

\section{Research Sample and Data Collection Procedures}

A total of 250 questionnaires were distributed to accounting practitioners attached to audit firms registered with the Malaysian Institute of Accountants (MIA). To facilitate the distribution of the questionnaires, the researchers sought the assistance of students of the researchers' institution who were undergoing practical training with the registered audit and accounting firms during the questionnaire distribution period. The respondents were politely approached by these students to request their participation in the survey. Each potential respondent received a cover letter and a copy of the questionnaire. The cover letter explained the purpose of the study and assured the confidentiality of answers given by respondents. It took respondents, on average, 15 minutes to complete the questionnaire. Two weeks after the distribution of the questionnaires, the students helped to collect the questionnaires from the respondents and passed them to the researchers. A total of 221 respondents completed the questionnaire, representing a response rate of approximately 88.4 percent.

\section{Data Analysis}

The data were analysed using the Statistical Package for the Social Sciences (SPSS) software. Basically, the descriptive statistics consist of frequency distributions and percentages were tabulated to develop demographic profiles of accounting practitioners in Malaysia. In addition, a descriptive analysis of the mean score and standard deviation were computed for the Likert-scale questions including the ethical ideology items and the ethical judgment for the vignettes. In testing the hypotheses, multiple regression models were developed. In the first two models that were relevant for testing hypotheses $\mathrm{H} 5, \mathrm{H} 6$, H8, H9, H11 and H12, the mean score of idealism or relativism was the dependent variable for each model while the independent variables were age, gender and professional qualification. The two relevant models are as follows:

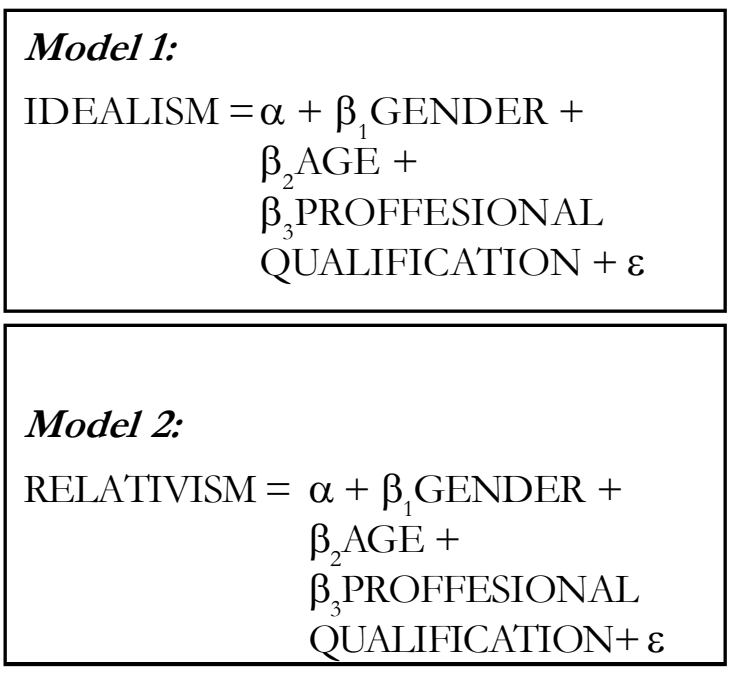

In testing the remaining hypotheses, a set of three regression models were used whereby for each model the score for ethical judgment was the dependent variable, while age, gender, professional qualification, idealism and relativism were the dependent variables. Of the three models, two represent the ethical judgment of each vignette and one model for the average ethical judgment score of the two vignettes. The models are as follows: 


\begin{tabular}{|l|}
\hline Model 3: \\
ETHICAL JUDGMENT $_{\text {OVERALL }}=\alpha+$ \\
$\beta_{1}$ GENDER $+\beta_{2}$ AGE + \\
$\beta_{3}$ PROFFESIONAL QUALIFICATION \\
$+\beta_{4}$ IDEALISM $+\beta_{5}$ RELATIVISM $+\varepsilon$ \\
\hline
\end{tabular}

\section{Model 4:}

ETHICAL JUDGMENT ${ }_{\text {ILLEGAL }}=\alpha+$ $\beta_{1} \mathrm{GENDER}+\boldsymbol{\beta}_{2} \mathrm{AGE}+$ $\beta_{3}$ PROFFESIONAL QUALIFICATION $+\beta_{4}$ IDEALI $+\beta_{5}$ RELATIVISM $+\varepsilon$

$$
\begin{aligned}
& \text { Model 5: } \\
& \text { ETHICAL JUDGMENT } \\
& \beta_{1} \text { GENDAL } \\
& \beta_{3} \text { PROFFESIONAL QUALIFICATION } \\
& +\beta_{2} \text { AGE }+ \\
& +\beta_{4} \text { DEALISM }+\beta_{5} \text { RELATIVISM }+\varepsilon
\end{aligned}
$$

where,

IDEALISM: Mean score of 10 relevant EPQ items measured on a 5 point Likert scale where $1=$ Strongly disagree; $5=$ Strongly agree

RELATIVISM: Mean score of 10 relevant EPQ items measured on a 5 point Likert scale where $1=$ Strongly disagree; $5=$ Strongly agree

ETHICAL JUDGMENT: Acceptability to ethical situation measured on a 7 point Likert scale where $1=$ Always acceptable; $7=$ Never acceptable

GENDER: $1=$ Male; $2=$ Female

AGE: $1=$ Less than 20 years; $2=20-29$ years; $3=30-39$ years; $4=40-49$ years; $5=50-60$ years
PROFESSIONAL QUALIFICATION: 1= holding an accounting professional qualification; $0=$ without an accounting professional qualification

\section{Findings and Discussion}

\section{Descriptive Statistics}

Table 1 depicts the demographic information of the respondents of this study with the majority of the respondents being female $(72.4 \%)$. Most of them were less than 30 years old $(76 \%)$ and, therefore, were new to the accounting career with less than five years of related working experience $(72.9 \%) ; 34.8$ percent of the respondents were professionally qualified accountants attached to either international or local professional accounting bodies.

In relation to the ethical ideology, the mean score for idealism of the respondents was 3.84 with a standard deviation of 0.51 , which was slightly higher than the relativism mean score of 3.51 and standard deviation of 0.574 . For the ethical judgment, the mean acceptability score for the illegal vignette was 5.36 and a standard deviation of 1.56, while the mean score for the legal vignette was 4.79 and a standard deviation of 1.77 . The average mean score of the two vignettes was 5.08 and a standard deviation of 1.28 . The results indicate overall less acceptability for both situations with even less acceptability for the illegal situation.

\section{Effect of Gender, Age and Professional Qualifications on Ethical Ideology}

Table 2 provides the findings of the two regression models, with idealism or relativism as the dependent variable, while age, gender, 
Table 1. Demographic Data

\begin{tabular}{|c|c|c|c|}
\hline & & Frequency & Percent \\
\hline \multicolumn{4}{|c|}{ Gender } \\
\hline & Male & 61 & 27.6 \\
\hline & Female & 160 & 72.4 \\
\hline & & 221 & 100 \\
\hline \multicolumn{4}{|l|}{ Age } \\
\hline & Less than 20 years & 4 & 1.8 \\
\hline & $20-29$ years & 167 & 74.2 \\
\hline & 30-39 years & 38 & 17.2 \\
\hline & 40-49 years & 9 & 4.1 \\
\hline & $50-60$ years & 6 & 2.7 \\
\hline & & 221 & 100 \\
\hline \multicolumn{4}{|c|}{ Working Experience in Accounting } \\
\hline \multirow[t]{6}{*}{ Field } & Less than 5 years & 161 & 72.9 \\
\hline & $5-10$ years & 33 & 14.9 \\
\hline & $11-15$ years & 11 & 5.0 \\
\hline & $15-20$ years & 5 & 2.3 \\
\hline & More than 20 years & 11 & 5.0 \\
\hline & & 221 & 100 \\
\hline \multicolumn{4}{|c|}{ Current Position } \\
\hline & Executive & 80 & 36.2 \\
\hline & Senior Executive & 32 & 14.2 \\
\hline & Manager & 16 & 7.2 \\
\hline & Senior Manager & 11 & 5.0 \\
\hline & Partner & 5 & 2.3 \\
\hline & Missing data & 77 & 34.8 \\
\hline & & 221 & 100 \\
\hline \multicolumn{4}{|c|}{ Professional Affiliation } \\
\hline & CPA & 5 & 2.3 \\
\hline & ACCA & 3.5 & 15.8 \\
\hline & MICPA & 3 & 1.4 \\
\hline & CIMA & 2 & 0.9 \\
\hline & Others & 32 & 14.5 \\
\hline & None & 144 & 65.2 \\
\hline & & 221 & 100 \\
\hline
\end{tabular}


Table 2. Determinants of Idealism and Relativism

\begin{tabular}{|c|c|c|c|c|}
\hline & \multicolumn{2}{|c|}{ Idealism } & \multicolumn{2}{|c|}{ Relativism } \\
\hline & Coeff & t-stat & Coeff & t-stat \\
\hline Constant & $3.431 * * *$ & 3.214 & $3.487 * * *$ & 15.95 \\
\hline Gender & $0.055^{* * *}$ & 2.310 & 0.07 & 0.793 \\
\hline Age & $0.121 * * *$ & 3.732 & -0.045 & -0.794 \\
\hline Professional qualification & -0.027 & -0.455 & 0.02 & 0.239 \\
\hline Adj R2 & \multicolumn{2}{|c|}{0.029} & \multicolumn{2}{|c|}{0.07} \\
\hline F-statistics & \multicolumn{2}{|c|}{$2.13 * *$} & \multicolumn{2}{|c|}{0.672} \\
\hline $\mathrm{N}$ & \multicolumn{2}{|c|}{221} & \multicolumn{2}{|c|}{221} \\
\hline
\end{tabular}

accounting professional qualification are the independent variables.

The results depict that gender has a positive significant effect on idealism at the 1 percent significance level. The results suggest that female accounting practitioners are more idealistic than their male counterparts. The finding lends support to evidence reported by Barnett et al. (1994 and 1996), Singhapakdi and Vitell (1994), Hartikainen and Tortilla (2004), Bass et al. (1998) and McHoskey (1996). Hence, hypothesis H5 is supported. Similarly, the effect of age on idealism was positively significant, which implies that older accounting practitioners were more idealistic than their younger counterparts, which is consistent with the finding claimed by Bass et al. (1998), and Hartikainen and Tortills (2004) in their studies. The finding, therefore, supports hypothesis $\mathrm{H} 8$.

The results concerning the effect of gender on relativism, however, were not significant, and therefore not supportive of hypothesis H6, which suggests that there is a difference in the relativism level of Malaysian male and female accounting practitioners. The results in Table 2 also reveal that professional qualification has no significant influence on either idealism or relativism. This indicates that regardless of whether or not the accounting practitioners were professionally qualified it did not influence their idealism or relativism levels. The results seem to support Bass et al.'s (1998) finding, however, they were in contrast with the evidence reported by Ho et al. (1997), and Singhapakdi et al. (1999) concerning the relationship between qualification and idealism. The findings, therefore, do not support hypotheses H11 and H12.

\section{Effect of Gender, Age, Professional Qualification and Ethical Ideology on Ethical Judgment}

Table 3 shows the results of the statistical analysis for the individual vignette as well the overall results on the effect of gender, age, professional qualification, idealism and relativism on the ethical judgment of accounting practitioners. Based on the overall results, ethical judgment was significantly influenced 
by all determinants except for professional qualification. The results suggest that female and older accounting practitioners had higher ethical attitudes than the male and younger practitioners. The results are consistent with the evidence of prior studies concerning the effect of gender (Akaah 1989; Ruegger and King 1992; Dawson 1997; Weeks et al. 1999; and Cohen et al. 2001) and age (Vittel 1986; Vitell et al. 1991; Ruegger and King 1992; and Rawwas and Singhapakdi 1998) on ethical judgment. Hence, hypotheses $\mathrm{H} 7$ and H10 are supported.

The results also indicate that more idealistic individuals have higher ethical attitudes than less idealistic individuals. However, this study also found that less relativistic individuals were less accepting to ethical situations than high relativistic individuals. The results concerning the positive (negative) relationship between idealism (relativism) and ethical judgment found in this study are consistent with previous studies, such as by Barnett et al. (1996), Doughlas et al. (2001), Kim (2003), Kleiser et al. (2003), Steenhout and Keenhove (2006), Greenfield et al. (2008) and Callanan et al. (2010). These findings, therefore, support hypothesis $\mathrm{H} 1$ and $\mathrm{H} 2$.

However, the results for the individual vignette are mixed. Although age and professional qualification remain a significant and insignificant influence, respectively, for both vignettes, the results for other factors are inconsistent. Gender had a significant effect on ethical judgment of the legally ethical vignette but was insignificant for the illegal ethical situation. This suggests that females are more sensitive to ethical issues as they are less accepting to questionable ethical issues regardless of the legality of the issues.

Table 3. Effects of Determinants on Ethical Judgment

\begin{tabular}{|c|c|c|c|c|c|c|}
\hline \multirow[t]{2}{*}{$\begin{array}{l}\text { Characteristics of } \\
\text { Respondents }\end{array}$} & \multicolumn{2}{|c|}{ Overall } & \multicolumn{2}{|c|}{$\begin{array}{c}\text { Illegal } \\
\text { Ethical Vignette }\end{array}$} & \multicolumn{2}{|c|}{$\begin{array}{c}\text { Legal } \\
\text { Ethical Vignette }\end{array}$} \\
\hline & Coeff & t-stat & Coeff & t-stat & Coeff & t-stat \\
\hline Constant & $2.688 * * *$ & 3.214 & $3.344 * * *$ & 3.318 & $2.032 *$ & 1.726 \\
\hline Gender & $0.609 * * *$ & 2.310 & 0.003 & 0.012 & $1.215^{* * *}$ & 4.693 \\
\hline Age & $0.446 * * *$ & 3.732 & $0.456 * * *$ & 3.165 & $0.436 * * *$ & 2.593 \\
\hline $\begin{array}{l}\text { Professional } \\
\text { qualification }\end{array}$ & -0.078 & -0.455 & -0.214 & -1.038 & 0.058 & 0.242 \\
\hline Idealism & $0.373 * *$ & 2.291 & $0.766 * * *$ & 3.901 & -0.019 & -0.085 \\
\hline Relativism & $-0.314 * *$ & -2.196 & $-0.544 * * *$ & -3.166 & -0.083 & -0.412 \\
\hline Adj R2 & \multicolumn{2}{|c|}{0.117} & \multicolumn{2}{|c|}{0.156} & \multicolumn{2}{|c|}{0.088} \\
\hline F-statistics & \multicolumn{2}{|c|}{$6.841 * * *$} & \multicolumn{2}{|c|}{$7.932 * * *$} & \multicolumn{2}{|c|}{$5.221 * * *$} \\
\hline $\mathrm{N}$ & \multicolumn{2}{|c|}{221} & \multicolumn{2}{|c|}{221} & \multicolumn{2}{|c|}{221} \\
\hline
\end{tabular}

$* * *$ significant at $1 \%, * *$ significant at $5 \%, *$ significant at $10 \%$ 
For the effect of ethical ideology on ethical judgment, the individual vignette whereby one vignette is legally ethical and the other is legally unethical, the results for the illegal case show a positive significant result but no significant result was found for the legally ethical situation. This implies that ethical ideology is a determinant for ethical judgment when the issue is a legally unethical matter. However, if the situation is ethically questionable but is legal based on the decision of the criminal court, the level of idealism and relativism will have no significant effect on an individual's ethical judgment. Thus, the finding supports hypotheses $\mathrm{H} 3$ but not hypothesis $\mathrm{H} 4$.

\section{Implications, Limitations and Conclusion}

The present study investigated the effect of age, gender and professional qualification on the ethical ideology of accounting practitioners in Malaysia. In addition, the study also examined the effects of demographic determinants and ethical ideology represented by idealism and relativism on ethical judgment in two ethical situations that are different in terms of the legality of the action. The study revealed several findings of interest to many parties including academicians, accounting practitioners and accounting professional bodies. First, this present study found that demographic determinants of age and gender significantly influenced the individual's idealism level and also had a significant effect on ethical judgment. Specifically, females and older accounting practitioners were more idealistic and less accepting to questionable ethical situations. However, no significant effect of age and gender was found on the relativism level of accounting practitioners. Second, the evidence of the present study showed that professional qualification had no significant influence on either the ethical ideology or ethical judgment of accounting practitioners in Malaysia. Third, this study discovered that idealism and relativism had a significant influence on the ethical judgment of accounting practitioners, particularly in an illegal ethical situation.

Even though the findings of this study revealed that ethical attitude moves directly with age, which supports Kohlberg's theory, awareness and sensitivity to an ethical issue is best if it could be instilled during the very early stage of an individual's career. To achieve this, the higher education system plays an important role. As ethical content already exists in most of the accounting modules, enhancing the effectiveness of the content delivery may help internalizing the ethical attitude among future accounting practitioners. Moreover, inculcating analytical thinking is also crucial in preparing the individuals to face real work life.

As for the professional accounting bodies, even though a professional accounting qualification is essential to being recognized in the profession, the present results illustrate that there is no difference between professionally qualified and non-professionally qualified practitioners in terms of their ethical judgment. To some extent, although the generalizability of the results is somewhat limited, it informs the accounting professional bodies that despite the present efforts to strengthen the ethical standards among their members the outcomes have yet to be proven. However, the findings indicate that accounting practitioners in Malaysia behave ethically regardless of whether or not they are professionally qualified.

This study is not without limitations. First, in relation to the generalizability issue, the present sample does not represent the popu- 
lation of accounting practitioners in Malaysia as only a small number of practitioners were covered in this study relative to a large population of accounting practitioners in Malaysia. Second, the ethical vignettes used as proxies for ethical judgment do not specifically reflect the daily real work ethical situations faced by the practitioners, and, hence, may not actually reflect the ethical attitude of the respondents in dealing with their daily work. Therefore, this is a potential area for improvement in future work in order to provide more insightful evidence. The third limitation of this present study is that it only considers a few factors affecting the ethical ideology and ethical judgment of the respondents. Future work may want to introduce other factors that may have influenced the ethical ideology and ethical attitudes of accounting practitioners such as socio-economic factors including level of income, education and work position. In addition, differences in culture could also be a factor to be taken into account as Hofstede
(1980 and 1998) claimed that Malaysia has a different culture than the western countries. Therefore, future work may want to include samples from at least two countries with different cultures (i.e. Malaysia and a western country) in assessing culture as a factor affecting ethical ideology and ethical judgment. Furthermore, future studies may want to consider a longitudinal study to investigate the ethical attitudes of accounting practitioners over time to see if the attitude changes due to certain initiatives that are introduced by responsible parties. Despite the limitations, this study contributes to the literature by offering some empirical evidence on factors affecting ethical ideology and ethical judgment of accounting practitioners. The evidence reported in this paper does not only confirm evidence reported in other prior literature which are mostly from the western countries, but more importantly, this present study made specific reference to samples from a developing country, which is still currently scarce.

\section{References}

Abdullah, Z. 2007. Mini-Enrons sharing up Malaysia's corporate governance? Accountants Today (July 2026).

Abu Bakar, N. B., S. Ismail, and S. Mamat. 2008. Ethics of future accounting professionals: Evidence from Malaysia. Journal of Financial Reporting and Accounting 6 (1): 21-33.

Akaah, I. 1989. Differences in research ethics judgments between male and female marketing professionals. Journal of Business Ethics 8: 375-381.

Arrington, C. E., and P. M. J. Reckers. 1985. A Social-psychological investigation into perceptions of tax evasion. Accounting and Business Research 15 (Summer): 163-176.

Barnett, T., K. Bass, and G. Brown. 1994. Ethical ideology and ethical judgment regarding ethical issues in business. Journal of Business Ethics 13: 469-480.

Barnett, T., K. Bass, and G. Brown. 1996. Religiosity, ethical ideology, and intentions to report a peer's wrongdoing. Journal of Business Ethics 15: 1161-1174.

Bass, K., T. Barnett, and G. Brown: 1998. The moral philosophy of sales managers and its influence on ethical decision making. Journal of Personal Selling and Sales Management 18 (2): 1-17. 
Borkowski, S. C., and Y. J. Ugras. 1998. Business students and ethics: A meta-analysis. Journal of Business Ethics 17 (8): 117-127.

Browning, J., and N. Zabriskie. 1983. How ethical are industrial buyers? Industrial Marketing Management 12 (4): 219-224.

Callanan, G. A., P. F. Rotenberry, D. F. Perri, and P. Oehlers. 2010. Contextual factors as moderators of the effect of employee ethical ideology on ethical decision-making. International Journal of Management 27 (1): 52-75.

Clark, J. W. 1966. Religion and The Moral Standards of American Businessmen. Cincinnati: South-Western Publishing Company.

Cohen, J., L. Pant, and D. Sharp. 2001. An examination of differences in ethical decision making between Canadian business students and accounting professionals. Journal of Business Ethics 30 (4): 319-336.

Dawson, L. 1997. Ethical differences between men and women in the sales profession. Journal of Business Ethics 16 (11): 1143-1152.

Deshpande, S. 1997. Managers' perception of proper ethical conduct: The effect of sex, age, and level of education. Journal of Business Ethics 16 (1): 79-85.

Douglas, P. C., R. A. Davidson, and B. N. Schwartz. 2001. The effect of organizational culture and ethical orientation on accountants' ethical judgments. Journal of Business Ethics 34: 101-121.

Dubinsky and Ingram. 1984. Correlates of salespeople's ethical conflict: An exploratory investigation. Journal of Business Ethics 3 (4): 343-53.

T. L. N. Emerson, S. J. Conroy, and C. W. Stanley. 2007. Ethical attitudes of accountants: Recent evidence from a practitioners' survey. Journal of Business Ethics 71: 73-87.

Fernando, M., S. Dharmage, and S. Almeida. 2008. Ethical ideologies of senior Australian managers: An empirical study. Journal of Business Ethics 82: 145-155.

Forsyth, D. 1980. A taxonomy of ethical ideologies', Journal of Personality and Social Psychology 39: 175-184.

Forsyth, D. K. 1981. Moral judgment: The influence of ethical ideology. Personality and Social Psychology Bulletin 7 (2): 218-223.

Forsyth, D. R. 1985. Individual differences in information integration during moral judgment. Journal of Personality and Social Psychology 49 (1): 264-272.

Forsyth, D. R., and J. L. Nye. 1990. Personal moral philosophies and moral choice. Journal of Research in Personality 24 (4): 398-458.

Forsyth, D. R. 1992. Judging the Morality of Business Practices: The Influence of Personal Moral Philosophies. Journal of Business Ethics 11: 461-470.

Forsyth, D., J. Nye, and K. Kelley. 1988. Idealism, relativism, and the ethic of caring. The Journal of Psychology 122 (3): 243-248.

Greenfield, A. C., C. S. Norman, and B. Wier. 2008. The Effect of ethical orientation and professional commitment on earnings management behavior. Journal of Business Ethics 83: 419-434.

Harris, J. 1991. Ethical values and decision processes of business and non-business students: A fourgroup study. The Journal of Legal Studies Education 9: 215-230.

Hartikainen, O., and S. Torstila. 2004. Job-related ethical judgment in the finance profession. Journal of Applied Finance (JAF) 14 (1): 62-76. 
Ho, F., S. Vitell, J. Barnes, and R. Desborde. 1997. Ethical correlates of role conflict and ambiguity in marketing: The mediating role of cognitive moral development. Journal of the Academy of Marketing Science 25 (2): 117-126.

Hofstede, G. 1980. Culture's Consequences. Thousand Oaks, CA: Sage.

Hofstede, G. 1998. Identifying organizational subcultures: An empirical approach. Journal of Management Studies 35 (1): 1-12.

Hunt, S. D., and S. Vitell. 1986. A general theory of marketing ethics. Journal of Macromarketing 6 (Spring): 5-16.

Jones, T., and F. Gautschi. 1988. Will the ethics of business change? a survey of future executives. Journal of Business Ethics 7 (4): 231-248.

Kidwell, J., R. Stevens, and A. Bethke. 1987. Differences in the ethical perceptions between male and female managers: Myth or reality. Journal of Business Ethics 6 (6): 489-493.

Kim, Y. 2003. Ethical standards and ideology among Korean public relations practitioners. Journal of Business Ethics 42: 209-223.

Kohlberg, L. 1969. Stages and sequences: The cognitive developmental approach to socialization. In D. Goslin (ed.), Handbook of Socialization Theory and Research: 347-480. Rand McNally, Chicago, IL.

Kohlberg, L. 1984. Essays on Moral Development (Vol. 2). The Psychology of Moral Development. San Francisco: Harper \& Row.

Kleiser, S. B., E. Sivadas, J. J. Kellaris, and R. F. Dahlstrom. 2003. Ethical ideologies: Efficient assessment and influence on ethical judgments of marketing practices. Psychology \& Marketing 20 (1): 1-21.

Longenecker, J. G., J. A. McKinney, and C. W. Moore. 1989. Ethics in small business. Journal of Small Business Management: 27-31.

Marques, P. A., and J. A. Pereira. 2009. Ethical ideology and ethical judgments in the Portuguese accounting profession. Journal of Business Ethics 86: 227-242.

McHoskey, J. 1996. Authoritarianism and ethical ideology. The Journal of Social Psychology 136 (6): 709-717.

Merritt, S. 1991. Marketing ethics and education: some empirical findings. Journal of Business Ethics 10 (8): 625-632.

Othman, Z., and R. Abdul Rahman. 2010. Ethics an Malaysian corporate governance practices. International Journal of Business and Social Science 1 (3): 98-109.

Radtke, R. 2000. The effects of gender and setting on accountants. Ethically sensitive decisions. Journal of Business Ethics 24 (4): 299-312.

Rawwas, M. Y. A., and A. Singhapakdi. 1998. Do consumers' ethical beliefs vary with age? A substantiation of Kohlberg's typology in marketing. Journal of Marketing Theory and Practice 6 (Spring): 26-38.

Razzaque, M., and T. Hwee. 2002. Ethics and purchasing dilemma: a Singaporean view. Journal of Business Ethics 35 (4): 307-326.

Reidenbach, R. E., and D. P. Robin. 1990. Towards the development of a multidimensional scale for improving evaluations of business ethics. Journal of Business Ethics 9: 639-653.

Roozen, I., P. De Pelsmacker, and F. Bostyn. 2001. The ethical dimensions of decision processes of employees. Journal of Business Ethics 33 (2): 87-99.

Ruegger, D., and E. King. 1992. A study of the effect of age and gender upon student business ethics. Journal of Business Ethics 11 (3): 179-186. 
Sankaran, S., and T. Bui. 2003. Ethical attitudes among accounting majors: an empirical study. Journal of the American Academy of Business 3 (1/2): 71-77.

Serwinek, P. 1992. Demographic and related differences in ethical views among small businesses. Journal of Business Ethics 11 (7): 556-566.

Shafer, W., R. Morris, and A. Ketchand. 2001. Effects of personal values on auditors' ethical decisions. Accounting, Auditing \& Accountability Journal 14 (3): 254-277.

Shaub, M. K., D. W. Finn, and P. Munter. 1993. The effects of auditors' ethical orientation on commitment and ethical sensitivity. Behavioral Research in Accounting 5: 145-169.

Schlenker, B. R., and D. R. Forsyth. 1977. On the ethics of psychological research. Journal of Experimental Social Psychology 13: 369-396.

Sikula, A., and A. Costa. 1994. Are women more ethical than men? Journal of Business Ethics 13 (11): 859871.

Singhapakdi, A., and S. Vitell. 1994. Ethical ideologies of future marketers: the relative influences of machiavellianism and gender. Journal of Marketing Education 16 (1): 34-42.

Singhapakdi, A., S. Vitell, and G. Franke. 1999. Antecedents, consequences, and mediating effects of perceived moral intensity and personal moral philosophies. Journal of the Academy of Marketing Science 27 (1): 19-36.

Stanga, K., and R. Turpen. 1991. Ethical judgements on selected accounting issues: An empirical study. Journal of Business Ethics 10 (10): 739-747.

Steenhaut, S., and P. Van Kenhove. 2006. An empirical investigation of the relationships among a consumer's personal values, ethical ideology and ethical beliefs. Journal of Business Ethics 64: 137-155.

Swaidan, Z., S. J. Vitell, and M. Y. A. Rawwas. 2003. Consumer ethics: determinants of ethical beliefs of African Americans. Journal of Business Ethics 46 (2): 175-186. 
